\title{
Some Flavonoids in the Yarrow (Achillea Millefolium L.) Plant and their Effects on Human Health
}

\author{
Numonjonov Mu hiddin Gulomjon ugli \\ Student of Andijan State University
}

Parpiyev Avazbek Teshaboy ugli

Student of Andijan State University

ABSTRACT: This article provides detailed information on the morpho-physiological characteristics, chemical composition, especially the amount of flavonoids and their function in the body and their role in human health, as one of the medicinal plants Achillea Millefolium L.

At the beginning of the article we will discuss in detail the role and distribution of the plant Achillea Millefolium L. in modern taxonomy. The properties, salinity and biochemical functions of apigenin and luteolin flavonoids, the most common flavonoids in this plant, are described in the article.

KEYWORDS: Achillea Millefolium L., pigenin, luteolin, flavonoids, chemical composition, drugs, vitamin $\mathrm{P}$, healing properties.

\section{INTRODUCTION}

The chemical composition of plants is complex and varied. In addition to carbohydrates, proteins and fats, they contain biologically active substance such as vitamins, enzymes, organic acids, phenols and their derivatives, essential oils, various glycosides, alkaloids, flavonoids, additives, minerals, which are useful and important for the human body. there is. These substances are involved in very important processes in our life activities.

Biologically active substances are formed as a result of continuous biochemical changes in plant cells. They change over time. As a result, they $t$ rn into other compounds, participate in the synthesis of complex molecular substances, or break down into simpler compounds, releasing energy from themselves.

Main part: Yarrow (Achillea Millefolium L.) is widespread in temperate regions of the Northern Hemisphere in Asia and Europe and North America, and in the desert and mountainous regions of Uzbekistan. A perennial plant $0.2-1 \mathrm{~m}$ tall (0.66-3.28 feet) and growing in a flat. The leaves are evenly distributed along the stem and are double-stalked, 5-20 cm long, almost hairy, and contain 
kaulin, which is sticky. The flowers are located in a large, compact thyroid inflorescence at the top of the stem, each cluster consisting of 1 or more flower heads. The inflorescence has 20-25 yellowishwhite (rarely pink) bright flowers. The fruit is flat, ovoid, gray pistachio. We can get acquainted with the modern systematic classification of plants on the basis of the following table.

The taxonomy of Yarrow (Achillea Millefolium L.) is shown in Table 1.

Table 1

\begin{tabular}{|c|c|}
\hline Section & Magnoliophyta \\
\hline Classis & Magnolipsida \\
\hline Ordo & Asterales \\
\hline Family & Asteraceae Dumort. \\
\hline Category & Achillea L \\
\hline Typus & Achillea Millefolium L \\
\hline
\end{tabular}

Chemical composition of Yarrow (Achillea Millefolium L.) includes biologically and chemically active substances carotene, vitamins $\mathrm{K}$ and $\mathrm{C}$, alkaloids achillein and betonicin, up to $0.8 \%$ essential oil, matricarin isomer, millefin lactone, $0.31 \%$ choline, asparagine, resin , astringent, bitter (proxamazulene-axillin) and other substances. The essential oil contains 1-4\% of hamazulen (the main part is formed from proxamazulene during the extraction of essential oil), thyme, camphor, borneol, carioffillen, up to $10 \%$ of cineole, formic, acetic and valeric acids.

Also flavonoids, including flavonoid glycosides, apigenin (Figure 1.) and luteolin (Figure 2.) tannins, the bitter compound achilein, choline, stachidrin; esters, caryophylene, formic, acetic and isovaleric acids.<smiles>O=c1cc(-c2ccc(O)cc2)oc2cc(O)cc(O)c12</smiles>

Figure 1. Apigenin

Flavonoids Flavonoids include phenolic compounds whose structure is diphenylpropane $\left(\mathrm{C}_{6}-\mathrm{C}_{3}-\mathrm{C}_{6}\right)$ and often derivatives of 2-phenylchroman (flavan) or 2-phenylchromone (flavon). It is based on the chemical classification of flavonoids on three main properties: the degree of oxidation of the carbon ring or the propane fraction; the size of the heterocycle (C); lateral case of phenyl. Depending on the degree of oxidation of the carbon skeleton, flavonoids are divided into several groups: flavones, flavonols, flavanones, isoflavones, anthocyanins, chalcones, catechins, aurons, and others. 
It is a large group of organic compounds that are chemically close to each other and have a common carbon skeleton. Some of them have the effect of vitamin P, which reduces the permeability and fragility of blood vessels. The flavonoids of some plants have herbal and diuretic properties. Because the first flavonoids isolated from plants were yellow, this group of compounds was called flavonoids (from the Latin word flavum - yellow).

Pure flavonoids (glycosides and aglycones) isolated from plants are colorless or orange and yellow crystalline substances. Glycosides of flavonoids are soluble in alcohol, poorly soluble in cold water, insoluble in ether, chlorophyll and other organic solvents, and aglycones are highly soluble in alcohol, ether and acetone and precipitate again after cooling.

Anthocyanins and their aglycones - The color of anthocyanins depends on the $\mathrm{pH}$ of the solution (or cell sap). Typically, this group of compounds is red, pink, orange in acidic conditions, and purple, blue, and blue in alkaline conditions. Flavonoids are brown and dark brown, dark red (taxifolin), yellow (quercetin, aurons, and most flavonoids), green-yellow (aureusidine, and other auroins) when exposed to UV light), dark green and orange (xanthones) and other colors. Most flavonoids are optically active, turning the plane of polarized light to the right or left.

The role of flavonoids in plant life is poorly understood. Recently, research is being conducted in this area. So far, the following points have been made:

1. Flavonoids are involved in the formation of the color of flowers and fruits of plants. This attracts insects and allows the flower to be pollinated.

2. Regulates the growth of plants.

3. Plays a role in plant resistance to disease. For example, when the leaf of the pea plant (Pisum sativum L) is infested with fungi, the leaf synthesizes the flavonoid physetin, which inhibits the growth of the fungus. Healthy pea leaves do not contain physetin.

4. It is believed that plants are actively involved in the process of oxidation and reduction in tissues. If we consider all the groups of flavonoids and assume the process of their transition from one to another, the above statement is true. This is because flavonoids are oxidized (meaning they can be reductive) or reversible (meaning they can act as oxidants) during the transition process.

Flavonoids are common in nature and are found in almost all higher plants. In particular, legumes (Fabaceae), astragalus - Asteraceae (complex flowers - Compositae), celery - Apiaceae (umbrella Umbelliferac), bears (Ranuncubaceac), perennials (Rosgonaceae), Roses (Polygonaceae), ragon and representatives of other families are rich in flavonoids. Animals do not synthesize flavonoids. This group of compounds is dissolved in the cell sap of all plant organs, and in some cases (underground organs and stems) in small amounts, up to $44 \%$ in the flowers and leaves of plants (in Saphora Japonica flowers). planadi. Flavonoids accumulate to their maximum concentration during the flowering period and then decrease.

Plants that grow in the southern hemisphere, as well as in open, sunny areas, typically synthesize more flavonoids than species that grow elsewhere. In nature, flavonol products are more abundant (40\% of flavonoids), and flavones, rings, and aurons are less common. Luteolin, which belongs to the flavonoid group of flavonoids, has a $\mathrm{C}_{6}-\mathrm{C}_{3}-\mathrm{C}_{6}$ structure and has two benzene rings $(\mathrm{A}, \mathrm{B})$, a third, an oxygen-containing (C) ring, and a 2-3 carbon double bond. Luteolin also has hydroxyl groups in the 5, 7, 3 'and 4' carbon tests (Figure 2). Hydroxyl fragments and 2-3 pairs of bonds are important structural properties of luteolin and are related to its biochemical and biological activity. As with

\begin{tabular}{c|c}
118 & $\begin{array}{c}\text { Published by "Global Research Network LLC" } \\
\text { https://grnjournals.us/index.php/AJSHR }\end{array}$
\end{tabular}


other flavonoids, luteolin is often glycosylated in plants and the glycoside is hydrolyzed to free luteolin during the absorption process. Some of the luteolin is converted to glucuronides as it passes through the intestinal mucosa. Luteolin is stable in heat and losses as a result of cooking are relatively low.<smiles>O=c1cc(-c2ccc(O)c(O)c2)oc2cc(O)cc(O)c12</smiles>

Figure 2. Luteolin

Luteolin is a flavonoid, a type of flavonoid, with a yellow crystalline appearance. Luteolin can act as an antioxidant or oxidant, and plants rich in luteolin have been used in traditional Chinese medicine. Luteolin is a major yellow dye compound derived from the Reseda luteola plant that has been used as a dye source since the first millennium BC. Luteolin was first isolated in pure form and named in 1829 by the French chemist Michel Eugene Chevreul. The empirical formula of luteolin was discovered in 1864 by the Austrian chemists Heinrich Hlasietz and Leopold Pfaundler. In 1896, the English chemist Arthur George Perkin proposed the correct structure of luteolin. Perkin's structure for luteolin was confirmed in 1900 when the Polish-Swiss chemist Stanislaw Kostanecki (1860-1910) and his students A. Rojitsky and J. Tambor synthesized luteolin.

Luteolin is most commonly found in leaves, but it is also found in bark, bark, clover flowers, and ragweed pollen. Salvia tomentosa from the Lamiaceae mint family is isolated from an aromatic flowering plant.

The importance of flavonoids in medicine. Yarrow is hemostatic (hemostatic) and anti-inflammatory properties Drugs in modern medicine used as an aerial part of yarrow. Hemostatic agent for local bleeding (from nasal, dental, small wounds; lung, fibroids, inflammatory processes). Used for diseases of the gastrointestinal tract. Colitis, peptic ulcer; also recommended for inflammation.

In short, biopolymers (proteins and peptides, $\mathrm{n}$ cleic acids and nucleotides, lipids, polysaccharides) and bioregulators (enzymes, vitamins, hormones) as well as alkaloids and flavonoids are important biologically and chemically active substances found in medicinal plants. Flavonoids are not only involved in physiological processes in plants, but they are also important for all living organisms. In particular, the flavonoid Luteolin in the plant Achillea Millefolium L. is a hemostatic agent for local bleeding in medicine (from nasal, dental, small wounds; lung, fibroids, inflammatory processes). It is 
used for diseases of the gastrointestinal tract. Therefore, it is important today to establish plantations rich in flavonoids and find ways to extract pure and large amounts of flavonoids in them.

\section{References:}

1. Kholmatov H.H, Ahmedov O.A "Pharmacognosy" Tashkent. Cholpon-2008

2. Ugli, F. S. F. Support of Stability of Protected Species of Plants in the Fergana Valley. International Journal on Integrated Education, 3(10), 29-31.

3. Foziljonov, S. (2021). THE DEGREE OF RARITY OF MEMBERS OF THE APIACEAE (UMBRELLIFEAE) FAMILY IN THE FERGANA VALLEY.

4. Pratov.O'.P, Nabiyev.M.M. “Modern system of higher plants of Uzbekistan” Tashkent. "O’qituvchi"- 2007. 31-32 pp.

5. Shukrullo, F. (2020). Protection OF Medicinal Plants and Increasing the Efficiency of Their Use. International Engineering Journal For Research \& Development, 5(6), 6-6.

6. Technology and ecology of medicinal plants. Tashkent. Thought Garden 2018.

7. Numonjonov M.G., Parpiyev A.T., Bozorboyev Sh.A., Vakhobova Sh.A. Alkaloids in some medicinal plants (CAPPARIS L, HYPERICUM L, ACHILLEA L, ) their structure and significance. SCIENCE AND EDUCATION scientific journal ISSN 2181-0842 volume 1, ISSUE 4. July 2020

8. Ugli, K. F. S., Rakhmonovich, T. H., Hakimovich, T. F., Hudoykulovich, U. N., \& Shukrullo, F. (2020). Quantity of silybum growing in uzbekistan methods of silimarin in the plant and methods of analysis of mass-spectrometry of flavolignanes in extract. European Journal of Molecular and Clinical Medicine, 7(3), 3703-3713.

9. Parpiyeva, M., Tuychiyeva, D., \& Numonjonov, M. (2020). EFFECTS OF HALOXYFOP-RMETHYLE AND INDOXACARB PESTICIDES ON THE STRUCTURE OF THE INTERNAL ORGANS OF RATS. Norwegian Journal of Development of the International Science, (45-2).

10. Ugli, F. S. F., \& Ugli, N. M. G. (2020). The effect of certain substances on the growth of pumpkin seeds. Science and Education, 1(4), 30-33.

11. No'monjonov Muhiddin Gulomjon O'G'Li, P. A. T., \& O'G'Li, B. S. A. (2020). ODDIY BO'YMODARON O'SIMLIGINING MORFO-FIZIOLOGIK TAVSIFI VA SHIFOBAXSH XUSUSIYATLARI. Science and Education, 1(4).

12. Nizomova. B, Numonjonov. M, Foziljonov. Sh. Biologically active substances in matrigaria plants and their medicinal properties. "International Conference on Mechanical Engineering Technology and Applied Sciences"

13. Murodali, T. (2021). Importance of Studying Location in Protection of Rare Plant Types: Fergana Valley. Middle European Scientific Bulletin, 9.

14. Foziljonov, S. (2020). BIODIVERSITY, ETHNOPHARMACOLOGYAND TAXONOMY OF GENUS PASSIFLORA. Студенческий вестник, (28-3), 31-33.

15. Foziljonov, S. (2021). THEORETICAL ANALYSIS OF THE DEGREE OF SCARCITY OF REPRESENTATIVES OF THE FAMILY OF Chenopodiaceae IN THE FERGANA VALLEY.

16. Foziljonov, S. "FARG 'ONA VODIYSI KAMYOB O 'SIMLIK TURLARI “ATLAS LUG’ATI.

17. Ugli, F. S. F. (2020). DETERMINATION AND CHEMICAL CLASSIFICATION OF MEDICINAL PLANTS GROWING ENVIRONMENT. BIOLOGICAL ACTIVE SUBSTANCES. INTERNATIONAL SCIENTIFIC AND TECHNICAL JOURNAL “INNOVATION TECHNICAL AND TECHNOLOGY”, 1(2), 77-80. 